\title{
CD95 expression in white blood cells of malnourished infants during hospitalization and catch-up growth
}

M.F. Nassar, ${ }^{1}$ S.R. El-Batrawy ${ }^{2}$ and N.M. Nagy ${ }^{3}$

$$
\begin{aligned}
& \text { تعبير الواسمة CD95 في الكريّات البيض لدى الرضَّع سيئي التغذية أثناء دخولمم المستشفى وخلال فتـرة النموّ } \\
& \text { التدارُكي } \\
& \text { مي فؤاد نصار، سلوى رضا البطر اوي، نادية ناجي }
\end{aligned}
$$

ABSTRACT Malnutrition continues to be a major health burden in developing countries. Flow cytometric estimation of the apoptotic marker CD95 in peripheral neutrophils, lymphocytes and monocytes was done for 18 infants with non-oedematous protein energy malnutrition (PEM) and 12 oedematous ones, on hospital admission and after supervised nutritional rehabilitation, and compared with 12 matched controls. CD95 counts in the 3 types of white blood cells were significantly higher in PEM infants and showed improvement after nutritional rehabilitation yet not reaching the control values. Enhanced apoptosis in the leukocytes of peripheral blood of PEM patients may be a marker of increased infection and immune disturbances. This derangement reverses upon proper nutritional rehabilitation.

Expression de CD95 dans les leucocytes des nourrissons souffrant de malnutrition pendant l'hospitalisation et lors du rattrapage de croissance

RÉSUMÉ La malnutrition continue de faire peser un lourd fardeau sanitaire sur les pays en développement. Une estimation par cytométrie en flux du marqueur apoptotique CD95 dans les neutrophiles, lymphocytes et monocytes périphériques a été réalisée chez 18 nourrissons présentant une malnutrition protéino-énergétique (MPE) sous sa forme non œdémateuse et chez 12 sous sa forme œdémateuse, lors de l'hospitalisation et après réadaptation nutritionnelle contrôlée ; les résultats ont ensuite été comparés à ceux de 12 témoins appariés. L'expression de CD95 dans les trois types de globules blancs était significativement plus élevée chez les nourrissons atteints de MPE et s'améliorait après la réadaptation nutritionnelle sans toutefois atteindre les valeurs témoins. Une augmentation de l'apoptose dans les leucocytes du sang périphérique des patients atteints de MPE peut être un marqueur d'infection accrue et de troubles immunitaires. Ce dérèglement disparaît avec une réadaptation nutritionnelle appropriée.

${ }^{1}$ Department of Paediatrics; ${ }^{3}$ Department of Clinical Pathology, Faculty of Medicine, Ain Shams University, Cairo, Egypt (Correspondence to M.F. Nassar:maie_nassar@yahoo.co.uk).

${ }^{2}$ Department of Anthropology, National Research Centre, Cairo, Egypt.

Received: 30/01/07; accepted: 14/03/07

المجلة الصحية لشرق المتوسط، منظمة الصحة العالمية، المجلد الخامس عشر، العلد ب، 9 +. 


\section{Introduction}

Malnutrition, both protein-energy malnutrition (PEM) and micronutrient deficiencies, continues to be a major health burden in developing countries. Globally it is the most important risk factor for illness and death. In these communities, a high prevalence of both poor diet and infectious disease exist in a vicious circle [1].

PEM in children is frequently associated with an increased incidence of bacterial, fungal and viral infections [2] and is the most common cause of secondary immunodeficiency [3-5]. Human and murine studies confirm that there is a significant degree of host immunosuppression in PEM, leading to increased morbidity and mortality. Apoptosis is a well-recognized process of cell death occurring as a series of changes in dying cells under several physiological conditions $[6,7]$ and has been implicated as an important mediator in the immunosuppression observed in several disease states [8]. Lymphocyte apoptosis has been described in peripheral blood and lymphatic organs during infection [9].

Blood cells with receptors for the apoptotic marker CD95 (Fas antigen) can be identified in peripheral blood using flow cytometry $[10]$ or polymerase chain reaction assay [11]. Identification of CD95 on various cells in the body was previously reported to be helpful in the diagnosis of a number of diseases and disorders $[12,13]$. Enhanced apoptosis in PEM patients was previously reported [14], but only on the peripheral blood lymphocytes using annexin $\mathrm{V}$ expression, which is not a direct cellular marker of apoptosis as CD95 expression.

This study of infants with PEM in Egypt was designed to assess CD95 expression to elucidate the apoptotic changes in different types of peripheral white blood cell (WBC) in the 2 subtypes of PEM, oedematous and non-oedematous, and to correlate these findings with the patients' clinical and laboratory parameters. Moreover, we aimed to assess the use of CD95 expression as a marker for following up these patients during their nutritional rehabilitation and its usefulness in predicting the prognosis of PEM patients.

\section{Methods}

\section{Patients}

The current study was performed on 42 infants recruited from the Children's Hospital, Ain Shams University, Cairo, Egypt during the period October 2005 to March 2006. The sample comprised 30 infants suffering from PEM and 12 clinically healthy ageand sex-matched controls. Infants suffering from chronic illnesses, chromosomal abnormalities and those on medication prior to enrolment were excluded from the study.

The infants with PEM were categorized into 2 groups according to Heird [15]. There were 18 non-oedematous infants $(8$ males and 10 females) with mean age 10.78 [standard deviation (SD) 4.72] months and 12 oedematous (4 males and 8 females) with mean age 11.67 (SD 4.92) months. They had appropriate birth weight and all had a dietetic cause for their condition starting after the first 6 months of life.

The controls were recruited among those presenting for dietetic advice, vaccination or circumcision (in males) at the outpatient clinic in the Children's Hospital, Ain Shams University. The control infants, 4 males and 8 females with mean age 13.17 (SD 6.45) months, had anthropometric measurements within the normal percentiles for their age and sex according to Ogden et al. [16].

\section{Data collection}

After obtaining the approval of the ethics committee at Ain Shams University Children's Hospital, informed written consent

المجلة الصحية لشرق المتوسط، منظمة الصحة العالمية، المجلد الخنامس عشر، العدد ب، 9 +. 
was obtained from the parents or legal guardians.

The parents of all the PEM cases and controls were asked to give a detailed dietary history, using a questionnaire written in simple Arabic language, with 24-hour recall of feeding.

All case and control children were given a thorough clinical examination, with collection of anthropometric measurements (weight, height, skull circumference and mid-arm circumference) to detect the type and degree of malnutrition in cases as well as a systemic examination to detect any other systems affected. Weight was measured on an electronic scale with minimal clothing and without shoes. Length was measured to the nearest $0.1 \mathrm{~cm}$ with a portable measuring board using standard procedures [17]. Skull circumference was measured to the nearest $0.1 \mathrm{~cm}$ with a metal tape. Weight, height and skull circumference were plotted against the percentiles to obtain the percentage of the median for age according to Ogden et al. [16]. Mid-arm circumference was measured at the middle of the left arm to the nearest $0.1 \mathrm{~cm}$.

For the laboratory workup clotted, venous blood and EDTA blood were collected under aseptic conditions from all children. Serum samples were used for the determination of serum albumin, urea, creatinine, alanine aminotransferase (ALT) and aspartate aminotransferase (AST) (Synchron CX-5 Delta, Beckman Instruments, California, United States of America) and C-reactive protein (CRP). The EDTA blood was used for complete blood count (CBC) (Coulter T660, Miami, United States of America) as well as estimation of CD95 in 3 types of WBC (neutrophils, lymphocytes and monocytes) by flow cytometry. The 3 cell types were separated by their forward versus side scatter distribution on plots.

After 2 months \pm 2 weeks of supervised nutritional rehabilitation according to the
WHO [18], re-evaluation of the PEM infants was done using the same pre-intervention measurements and investigations.

\section{Nutritional rehabilitation}

After the management of life-threatening and emergency conditions in the PEM infants, supervised feeding was started. Caloric intake during the first week of treatment was 80-100 kcal/kg/day, keeping in mind the continuity of breastfeeding in the case of breastfed infants. The diet given was low in protein, fat and sodium and high in carbohydrates, as almost all severely malnourished infants have infections, impaired liver and intestinal functions and problems related to electrolyte imbalance.

With the return of the infant's appetite, the calorie intake was increased to 150-200 $\mathrm{kcal} / \mathrm{kg} /$ day with increases in the amounts and decreases in the frequency. A highprotein diet was given and vitamins and minerals (potassium, magnesium and zinc) were continued in increased amounts. Iron was given during this stage to treat anaemia. The infant remained in hospital for the first part of this rehabilitation phase (3 weeks after admission), and was then followed up in the nutritional rehabilitation outpatient clinic.

\section{Statistical analysis}

Statistical analysis was done using SPSS, version 10 and Statistica, version 5. The Kolmogorov-Smirnov test was used to detect non-parametric data. Student $t$-test was used for parametric data and MannWhitney test for non-parametric data. To compare values before and after nutritional rehabilitation, paired $t$-test was used for parametric data and Wilcoxon signed rank test for non-parametric data. Correlation studies were also done. The numerical data were represented as mean (SD) and median (interquartile range). The differences were considered significant at $P<0.05$. 


\section{Results}

Anthropometric measurements were lower in non-oedematous and oedematous PEM infants compared with controls (Table 1). These showed significant improvement after nutritional rehabilitation (but still did not reach the control values in most of the infants) except for the mid-arm circumference in oedematous patients which showed almost no change at follow-up (Table 2).

Serum albumin and haemoglobin levels showed significant improvement before and after nutritional rehabilitation without reaching the control values (Tables 1 and 2). Total leukocyte count was significantly higher in both PEM groups compared with the controls and decreased after nutritional rehabilitation (Tables 1 and 2).

There were no significant differences in the anthropometric measurements and laboratory parameters between the oedematous and non-oedematous PEM patients, except for significantly lower weight and higher serum albumin in the non-oedematous group (Table 1). Liver and kidney functions were within the normal range for age and sex from the start of the study, according to Nicholson and Pesce [19].

The CD95 counts in peripheral neutrophils and lymphocytes in PEM infants, oedematous and non-oedematous, were significantly higher compared with the controls (Table 3). CD95 levels in monocytes were also higher in PEM infants compared with controls, but this was only significant for the non-oedematous group (Table 3). There was also a non-significant difference between the non-oedematous and oedematous PEM patients as regards the CD95 level in the 3 WBCs (Table 3). The CD95 expression in the 3 types of cell showed improvement after nutritional rehabilitation, although not reaching control values, but this was significant only for neutrophils and lymphocytes (Figures 1-3).
Although CD95 expression in neutrophils showed no significant correlation with weight-for-age, it showed significant negative correlation with each of the initial values in the PEM patients for percentage length-for-age $(r=-0.39 ; P<0.05)$, skull circumference $(r=-0.67 ; P<0.001)$ and serum albumin $(r=-0.36 ; P<0.05)$, with no significant difference after nutritional rehabilitation $(r=-0.04, r=-0.13$ and $r$ $=-0.21$ respectively; $P>0.05$ for all). Additionally, significant positive correlation was found between CD95 expression in neutrophils and initial and follow-up CRP values in PEM infants $(r=0.80 ; P<0.001$ and $r=0.36 ; P<0.05$ respectively).

\section{Discussion}

The present study showed enhanced apoptotic tendency in the 3 types of WBC in PEM patients, regardless of the type of malnutrition. Increased CD95 expression was evident in the neutrophils, lymphocytes and monocytes. Neutrophils are known to protect the body against pyogenic infections. Their function is closely related to that of lymphocytes and macrophages (activated monocytes in tissues) [20]. Thus the results of our study suggest that the body's protection against infection is impaired in PEM patients, as shown by the significant positive correlation between CD95 expression in neutrophils and CRP values in PEM patients. Additionally, the increased apoptotic tendency detected here depended on the severity of the PEM condition since it showed a significant negative correlation with the initial anthropometric measurements and serum albumin.

The enhanced apoptosis we found in PEM patients agrees with El-Hodhod et al., although they detected increased apoptotic tendency only in peripheral blood lymphocytes of PEM patients using annexin $\mathrm{V}$

المجلة الصحية لشرق المتوسط، منظمة الصحة العالمية، المجلد الخامس عشر، العدد ب، 9 +. 


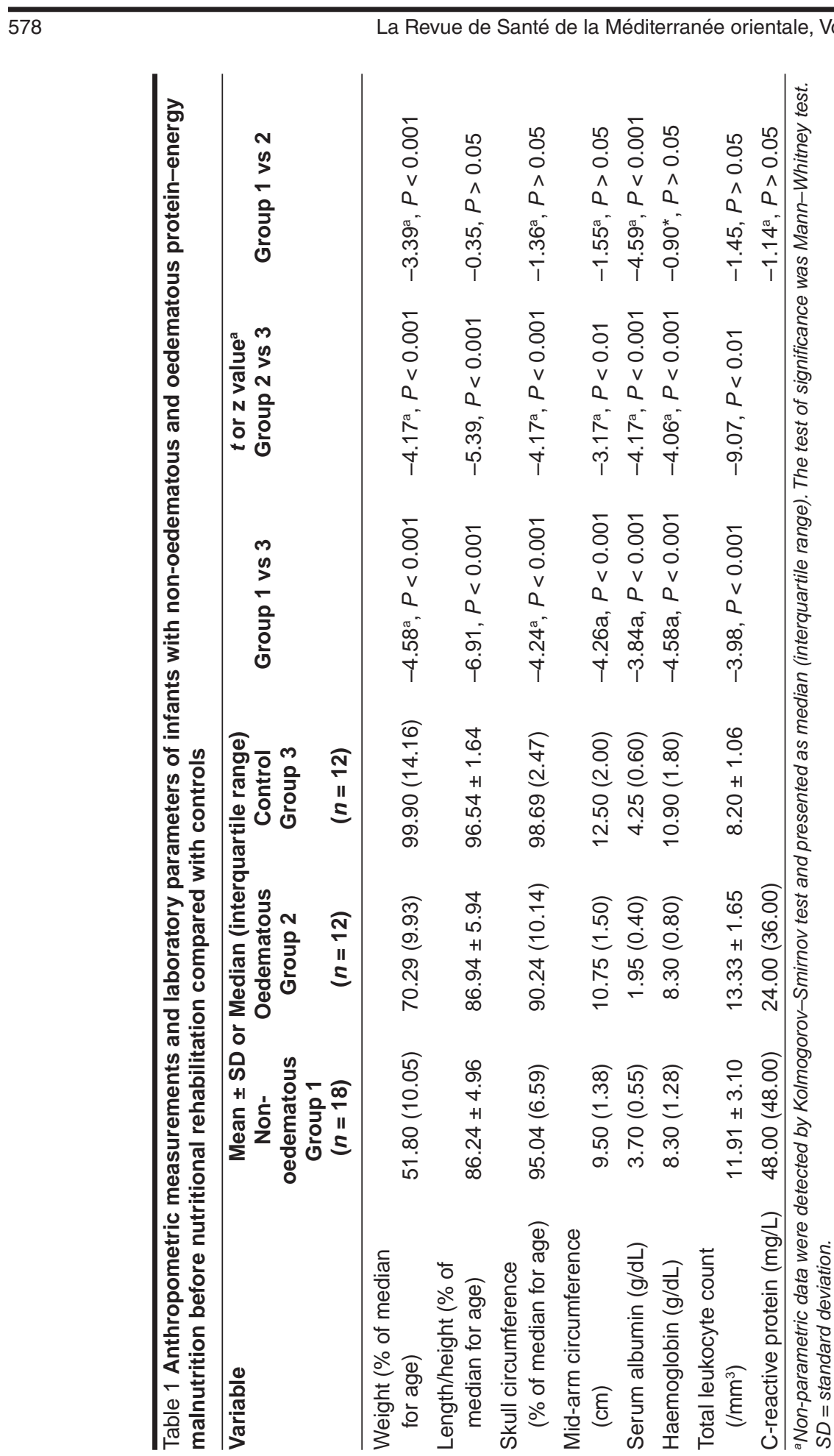

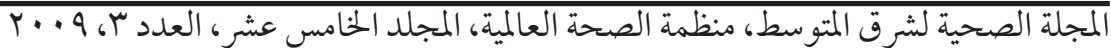




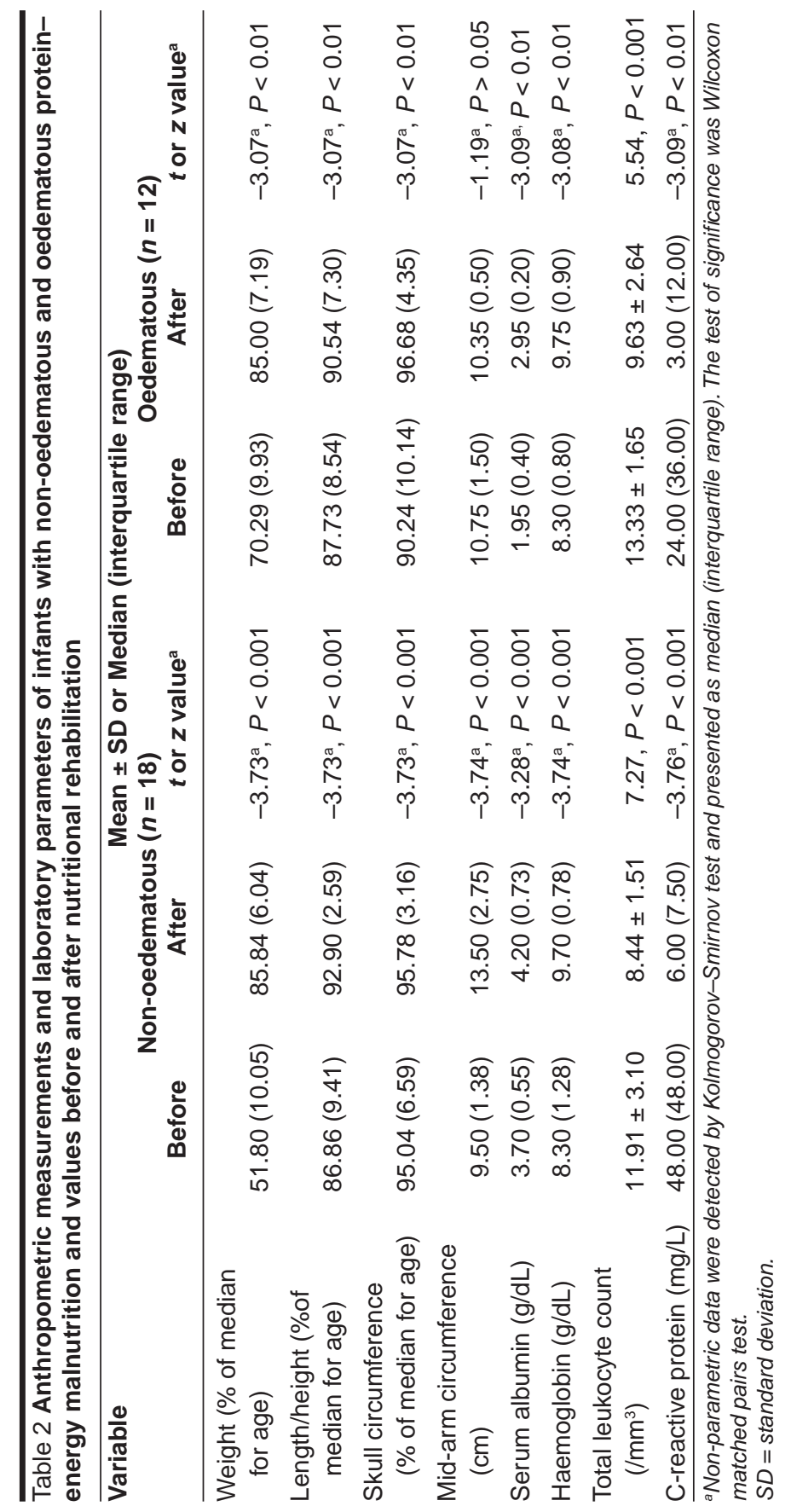

المجلة الصحية لشرق المتو سط، منظمة الصحة العالمية، المجلد الخامس عشر، العدد ب، 9 +. 
assay [14]. They correlated this finding with the increased incidence of infection in their series of patients. Our results also agree with previous murine studies. Enhanced macrophage apoptosis in a murine model of PEM was reported by Rivadeneira et al. [8]. As in our study and that of El-Hodhod et al. [14], they suggested that their findings may help to explain the associated immune dysfunction observed in malnutrition.

Additionally, Reddy Avula et al. reported increased Fas and Fas-L gene expression which closely correlated with enhanced apoptosis of lymphocytes in mice fed calorierestricted diets [21]. An interesting aspect of this finding was raised by these authors. They suggested that this may contribute to the known beneficial effects of calorie restriction such as prolongation of lifespan by activating chronic physiologically mediated apoptosis.

Disturbed levels of macro- and micronutrients that occur in PEM could be the cause of the enhanced apoptosis seen here. For instance, deprivation of various amino acids or glucose induces cell cycle arrest and cell death [22]. Additionally, folate deficiency enhances apoptosis in lymphocytes [23] and studies of zinc deficiency have become important for demonstrating that nutritional imbalances can readily induce apoptosis in a variety of cell types [24]. Moreover, Savino reported that malnutrition secondary to deficiency in uptake of proteins, metal elements or vitamins, consistently results in changes in the thymus gland [25]. Thus these macro- and micronutrient deficiencies can act directly or via apoptosis-induced thymocyte depletion. In fact, in 2001, Ortiz et al. proposed a theory for enhanced apoptosis in experimentally malnourished rats: the greater levels of spontaneously apoptotic cells associated with malnutrition could be related to alterations of the microenvironment of the

المجلة الصحية لشرق المتوسط، منظمة الصحة العالمية، المجلد الخامس عشر، العدد ؟، 9 + · 


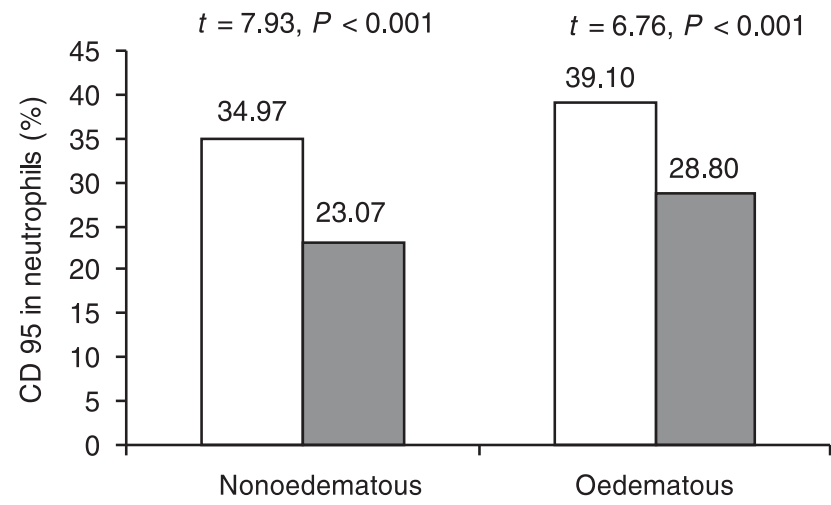

$\square$ Before $\square$ After

Figure 1 Neutrophil CD95 levels in infants with non-oedematous and oedematous proteinenergy malnutrition before and after nutritional rehabilitation

thymus and/or to an obstruction of early thymocyte maturation [7].

We can speculate that this enhanced apoptosis detected in PEM patients could be attributed to either the malnourished status

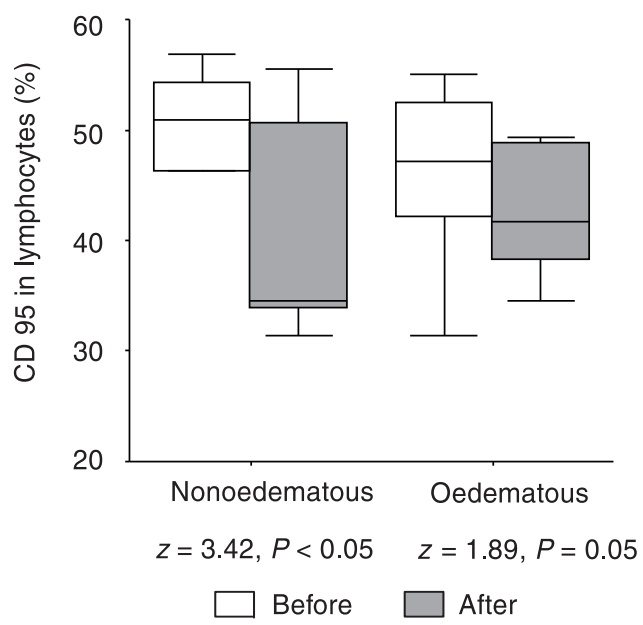

Figure 2 Lymphocyte CD95 levels in infants with non-oedematous and oedematous protein-energy malnutrition before and after nutritional rehabilitation itself or be a consequence of the recurrent infections. What favours the former theory is the demonstration of improved apoptotic process on nutritional rehabilitation accompanied by clinical improvement, despite the

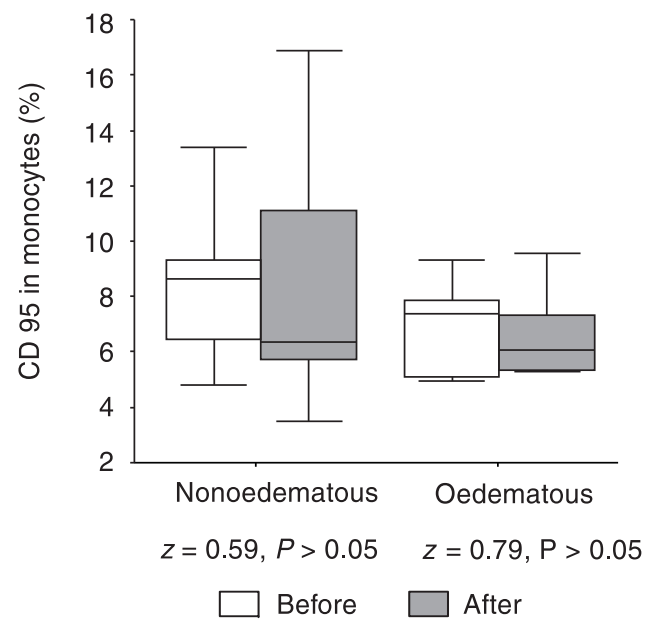

Figure 3 Monocyte CD95 levels in infants with non-oedematous and oedematous protein-energy malnutrition before and after nutritional rehabilitation

المجلة الصحية لشرق المتوسط، منظمة الصحة العالمية، المجلد الخامس عشر، العدد ؟، 9 +. 
persistence of the significant correlation between CD95 expression on neutrophils and CRP.

Enhanced apoptosis could explain the pathogenesis of many organ dysfunctions that occur in PEM patients, for instance, cardiac malfunctions as described by ElSayed et al. [26] and exocrine pancreatic dysfunction reported by El-Hodhod et al. [14]. This suggestion awaits further verification on appropriate animal models.

In conclusion, there is enhanced apoptosis in the peripheral blood of PEM patients, regardless of the type of PEM, and this is suggested as a cause of increased infection and immune disturbances in those patients.
Larger-scale studies are suggested to further elucidate this point and demonstrate the enhanced apoptotic tendency in other types of blood cell and subpopulations of lymphocytes as well as various other organs to emphasize the role of apoptosis in the morbidity and mortality from such disease. Although this apoptotic tendency reverses with proper nutritional rehabilitation, follow-up studies are also recommended to verify the point raised by other authors about the beneficial effects of calorie restriction in prolongation of lifespan, bearing in mind that in PEM, calorie restriction would have occurred only at an early period of the patient's life.

\section{References}

1. Muller O, Krawinkel M. Malnutrition and health in developing countries. Canadian Medical Association journal, 2005, 173(3):279-86.

2. Schopfer K, Douglas SD. Neutrophil function in children with kwashiorkor. Journal of laboratory and clinical medicine, 1976, 88:450-6.

3. Chandra RK. Marginal malnutrition and immunocompetence. In: Harper AE, Davis GK, eds. Symposia from the XIIth International Congress on Nutrition. New York, Alan R Liss, 1981:261-5.

4. Fraker PJ, King LE. A distinct role for apoptosis in the changes in lymphopoiesis and myelopoiesis created by deficiencies in zinc. FASEB journal, 2001, 15(14):2572-8.

5. Islam Z et al. Endotoxin potentiation of trichothecene-induced lymphocyte apoptosis is mediated by up regulation of glucocorticoids. Toxicology and applied pharmacology, 2002, 180(1):43-55.

6. Howie SE, Harrison DJ, Wyllie AH. Lymphocyte apoptosis: mechanisms and implications in disease. Immunological reviews, 1994, 142:141-56.

7. Ortiz $\mathrm{R}$ et al. Flow cytometric analysis of spontaneous and dexamethasoneinduced apoptosis in thymocytes from severely malnourished rats. British journal of nutrition, 2001, 86(5):545-8.

8. Rivadeneira DE et al. Malnutrition-induced macrophage apoptosis. Surgery, 2001, 129(5):617-25.

9. Zuñiga $E$ et al. Apoptosis de linfocitos asociada a enfermedades infecciosas [Lymphocyte apoptosis associated to infections]. Medicinia (B Aires), 2002, 62(2):189-96.

10. Wu CC et al. Apoptotic markers on lymphocytes and monocytes are unchanged during single hemodialysis sessions using either regenerated cellulose or polysulfone membranes. Clinical nephrology, 2005, 64(3):198-204.

11. Sawhney et al. Age related changes in Fas (CD95) and Fas ligand gene expression and cytokine profiles in healthy Indi- 
ans. Asian Pacific journal of allergy and immunology, 2006, 24(1):47-56.

12. Wei et al. CD95-induced osteoarthritic chondrocyte apoptosis and necrosis: dependency on p38 mitogen activated protein kinase. Arthritis research and therapy, 2006, 8(2):R37.

13. Fischer-Posovszky $P$ et al. Role of CD95mediated adipocyte loss in autoimmune lipodystrophy. Journal of clinical endocrinology and metabolism, 2006, 91(3):1129-35.

14. El-Hodhod MA et al. Apoptotic changes in lymphocytes of protein energy malnutrition patients. Nutrition research, 2005, 25:21-9.

15. Heird WC. Food insecurity, hunger and undernutrition. In: Behrman RE, Kliegman RM, Jenson HB, eds. Nelson textbook of pediatrics, 17th ed. Philadelphia, WB Saunders, 2004:167-73.

16. Ogden $C L$ et al. Centers for disease and prevention 2000 growth charts for the Unites States: improvements to the 1997 National Center for Health Statistics version. Pediatrics, 2002, 109(1):45-60.

17. Jelliffe DB. The assessment of the nutritional status of the community (with special reference to field surveys in developing regions of the world). Geneva, World Health Organization, 1966:3-271 (WHO Monograph Series No. 53).

18 Management of severe malnutrition: a manual for physicians and other senior health workers. Geneva, World Health Organization, 1999.
19. Nicholson JF, Pesce MA. Reference ranges for laboratory tests and procedures. In: Behrman RE, Kliegman RM, Jenson $\mathrm{HB}$, eds. Nelson textbook of pediatrics, 17th ed. Philadelphia, WB Saunders, 2004:2396-427.

20. Smolen JE, Boxer LA. Functions of neutrophils. In: Beutler E et al., eds. Williams textbook of hematology, 6th ed. New York, McGraw-Hill, 2001:761-84.

21. Reddy Avula CP et al. Calorie restriction increases Fas/Fas-ligand expression and apoptosis in murine splenic lymphocytes. FEBS letters, 1999, 458(2):231-5.

22. Ishii $T$ et al. Nutritional deficiency affects cell cycle status and viability in A549 cells: role of p27Kip1. Cancer letters, 2004, 213(1):99-109.

23. Lin $\mathrm{HL}$ et al. In vitro folate deficiency induces apoptosis by a p53, Fas (Apo-1, CD95) independent, bcl-2 related mechanism in phytohaemagglutinin-stimulated human peripheral blood lymphocytes. British journal of nutrition, 2006, 95(5):870-8.

24. Fraker PJ. Roles for cell death in zinc deficiency. Journal of nutrition, 2005 135(3):359-62.

25. Savino W. The thymus gland is a target in malnutrition. European journal of clinical nutrition, 2002, 56(Suppl. 3):S46-49.

26. El-Sayed HL et al. Structural and functional affection of the heart in protein energy malnutrition patients on admission and after nutritional recovery. European journal of clinical nutrition, 2006, 60:502-10. 